\title{
In Terram Visionis
}

\section{The Image of Abraham in Nicephorus Choumnus' Homily on the Transfiguration (BHG 1998w)}

\author{
Dmitry I. Makarov
}

The Ural State Conservatoire, Yekaterinburg

dimitri.makarov@mail.ru

\begin{abstract}
In his Transfiguration homily (ca. 1315) Nicephorus Choumnus, a pre-Palamite thinker, put forward a theory that Abraham at the oak of Mamre was granted the vision of the Trinity. This is the third type of the exegesis of Genesis 18, according to Lars Thunberg. By comparison with: (a) Gregory of Nyssa and other patristic authors; (b) the early second-century Testament of Abraham (TA) we have put forward a hypothesis that Abraham, in Choumnus' view, was granted the vision of the divine light and glory, most likely, in the form of a bright cloud very similar to that which later overshadowed the elected of the prophets and the Apostles on Mount Tabor. Thus, Nicephorus Choumnus mentioned Abraham together with such symbolic oт figures, as Moses and Elijah, who had also the honor of seeing the Face of God on Tabor.
\end{abstract}

\section{Keywords}

Nicephorus Choumnus - Origen - Testament of Abraham - Abraham - vision of God - the oak at Mamre - Tabor - Transfiguration

* This research was carried out with the help of the Russian Foundation for Humanities, grant Nr 15-03-00665 "The Variety of Humanism and Its Ways: The Intellectual Legacy of the Late Byzantium, Thirteenth to Fourteenth Centuries." 
In 1315 or 1316 , the Byzantine statesman and intellectual Nicephorus Choumnus (ca. 1250/1255-16.01.1327) $)^{1}$ wrote a homily On the Holy Transfiguration of Christ. ${ }^{2} \mathrm{He}$ preached this sermon during the Vespers on the feast of Transfiguration in the Constantinople double monastery of the Philanthropos Saviour, addressing it to the monks and nuns at the same time. ${ }^{3}$ It is difficult to identify all ideas, which the author borrowed from his predecessors in long tradition of the homiletics of the feast. ${ }^{4}$ I will try to shed some light on a partial solution to this huge task by tackling the problem of Choumnus' interpretation of Abraham. The way Choumnus treated the image of Abraham in his homily is not typical for the Byzantine tradition of homiletics. Therefore, I will attempt to determine those theological traditions, which might have served as the basis for Choumnus. The very existence of a cluster of several theological, ascetical and exegetical trends, which exerted their influence on educated Byzantines of the thirteenth and fourteenth centuries, seems to me being not only an axiom, but also a scholarly provable fact.

Why did Choumnus in his homily pay closer attention to Abraham $?^{5}$ What is the theological importance of the figure and what could have been its possible sources?

Choumnus numbers Abraham in the assembly of those prophets, like Moses and Elijah, who already deserved to meet the Son of God here on earth. Christocentrism is an essential feature of the world view of Choumnus. ${ }^{6}$

1 A.M. T[albot], "Choumnos Nikephoros," in: Oxford Dictionary of Byzantium, ed. A.P. Kazhdan, Vol. 1, Oxford-New York, 1991, p. 433; PLP 30961.

2 The manuscripts ВРФ give another reading of the title: On the holy and fearful Transfiguration

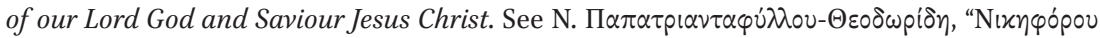

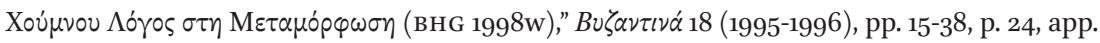
crit. See on the dating in: J. Verpeaux, Nicéphore Choumnos, homme d'État et humaniste byzantin (ca 1250/1255-1327), Paris, 1959, p. 55; PLP 30961 (following J. Verpeaux). The title of Gregory of Sinai's homily on the same theme ( $c a .1346)$ is the closest to the one by Choumnos: Homily on the Holy Transfiguration of our Lord Jesus Christ. See D. Balfour (ed.), Saint Gregory the

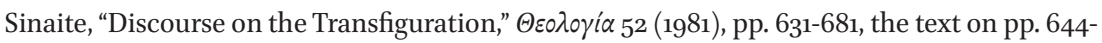
681. See on the dating: Ibid., p. 633.

3 On the destination of the homily one can read in a brief note in the manuscript $\mathrm{P}$ (f. $89^{\text {rv }}$ ). The

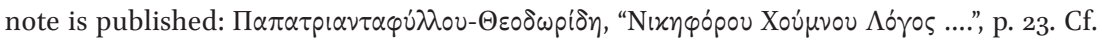
editor's comment: ibid., p. 22.

4 Ibid., pp. 19, 20.

5 See the Chapters from eleventh to seventeenth: ibid., pp. 29.171-33.308.

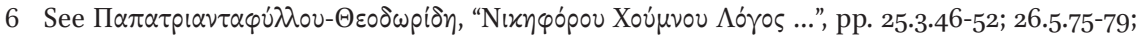
35.21.349-350. Hereinafter I will give references to the edition in the main text, with the indication of the page(s) number(s), of the number of a chapter and of that of the line(s). 
Seeing Abraham from this angle, Nicephorus uncovers the principal traits of the от patriarch. I will enumerate these traits in the following lines:

- Abraham's personal righteousness is most importantly characterized in hospitality;

- Abraham beheld the vision of God under the oak of Mamre (Gen. 18) as the crown of faith. Thus, Abraham turned out to be that righteous person about whom the от prophets spoke: ${ }^{7}$ mean Hab. 2, 4-the verse which was quoted thrice in the NT (Rom. 1, 17; Gal. 3, 11; Heb. 10, 38) and which was used there "as a summary of the Pauline theology";

- Abraham, as a consequence of all the above happened, appeared as one of the forerunners of Christ (cf. Jn. 8, 56-58), i.e., he was treated by Choumnus as a member of the assembly of those who were overshadowed with the luminous cloud of the divine glory (LK. 9, 32; Jn. 1, 14; cf. also 2 Peter 1,16$) ; 9$

- Abraham had also the honor to see the Holy Trinity at the same place (p. 30.12.190-191; cf. p. 30.13.201-203). This is the third type of the exegesis of Genesis 18, according to Lars Thunberg, and it was represented by Cyril of Alexandria and Maximus the Confessor. ${ }^{10}$ It became predominant in Byzantium since the turn of the fourth and the fifth centuries. ${ }^{11}$ Following the third type in question, Choumnus correlated the place under the oak and the table with food, where God himself sat, with the Tabor as the Mount of the Transfiguration. So the way, in which God had appeared to

7 Abraham himself was called in the от a prophet (Gen. 20, 7).

8 J.J. Collins, Introduction to the Hebrew Bible and Deutero-Canonical Books, Minneapolis², 2014, p. 351; cf. B. Chilton, J. Neusner, Judaism in the New Testament: Practices and Beliefs, London-New York, 1995, p. 103, cf. p. 102. Cf. Gen. $15,6$.

9 Choumnus' understanding of that theophany which appeared to Abraham is identical to one of the three formulations of a conventionally 'typological' exegesis of the Mamre account. B.G. Bucur put it thus: “... Abraham encountered the Word of God in a theophany that anticipates the incarnation of the Word" (B.G. Bucur, "The Early Christian Reception of Genesis 18: From Theophany to Trinitarian Symbolism," Journal of Early Christian Studies, 23 (2015), pp. 245-272, p. 268. The idea is traceable back to Larry Hurtado; cf. ibid., pp. 269-270). It means that Nicephorus puts strong emphasis on the Christology.

10 L. Thunberg, "Early Christian Interpretations of the Three Angels in Gen. 18," in: $S P, 7 / 1$ (1966), pp. 360-370, here p. 361, 365-369. According to the first-Jewish-type of exegesis, it was three archangels Michael, Gabriel and Raphael who manifested themselves to Abraham (Bucur, "The Early Christian Reception ...", pp. 248-249; n. 10). In his turn, Timothy of Antioch was a representative of the second type when he wrote that Abraham had seen the Son of God flanked by two angels and, for that reason, he prepared only one table, so as to salute the Sovereign (Timothei Antiocheni, Sermo in Crucem et in Transfigurationem Domini nostriJesu Christi, in $P G$ 86, col. 264C). 
Abraham, may be juxtaposed, at least in a symbolic manner, to that luminous cloud (Lk.9, 32) which overshadowed the mount.

These traits of Abraham in Choumnus' homily may be reduced to the four main items: hospitality, faith, instruction in the divine Law, and the vision of God. As a result of them all, the fifth feature arises, i.e. Abraham being a forerunner of Christ in the history of salvation.

What are, then, the specific features in Choumnus' comprehension of these traits, and which might have been possible sources of his vision of Abraham?

Among the variety of theological traditions, which had never ceased to exist in Byzantium and could not have but exerted some influence upon our author, I will single out two main levels, namely, the primary level, which was connected with the patristic tradition, and the secondary level. The primary level is associated with the treatment of Abraham in Gregory of Nyssa, which presumably exerted a stimulating influence upon the Second and Third Monastic Discourses by Theoleptos of Philadelpheia. ${ }^{12}$ There is also an important remark on Abraham in Nicetas Stethatos' polemical treatise against the Latins. The impact of Theoleptos upon Choumnus is certainly beyond doubt: Theoleptos was well acquainted with Choumnus during the late, Constantinople period of both intellectuals' life; they both used to visit the monastery of Philanthropos Saviour and pray there, and it was Choumnus' daughter Irene-Eulogia Choumnaina who became a nun in the monastery $c a .1307$.

The secondary level seems to be determined by the early second-century Jewish apocryphal text $\left(c a .75^{-125},{ }^{13} \text { or } c a .115^{-117}\right)^{14}$ The Testament of Abraham, extant in Greek (hereinafter TA; BHG 2001, the shorter version $B H G$ 2002). The manuscripts of $T A$ were certainly in circulation in the fourteenth century. ${ }^{15} T A$

12 MD 5 (On the Transfiguration of the Lord) could not have exerted an influence upon Choumnus, because it was composed two or three years later, $c a$. 1318, and did not mention Abraham. See R.E. Sinkewicz, Theoleptos of Philadelpheia, The Monastic Discourses, Toronto, 1992, pp. 186-191; A. Rigo, "La Trasfigurazione di Cristo sul monte Tabor nelle opere di Gregorio il Sinaita," in: Il Cristo Trasfigurato nella tradizione spirituale ortodossa. Atti del XV Convegno ecumenico internazionale di spiritualità ortodossa, eds. S. Chialà, L. Cremaschi, A. Mainardi, Bose, 2008, pp. 277-291, here p. 291.

E.P. Sanders, "Introduction," in: E.P. Sanders (trans. and introd.), "The Testament of Abraham (First to Second Century AD)", in: The Old Testament Pseudepigrapha, Vol. 1, Apocalyptic Literature and Testaments, ed. J.H. Charlesworth, New York, 1983, pp. 871-881, p. 875 .

14 Bucur, “The Early Christian Reception ...", p. 249, n. 10.

15 Three manuscripts, dating back to the eleventh century, are known, while other thirty manuscripts (from those used by F. Schmidt in his edition) predate fourteenth century. There are four manuscripts of the fourteenth century, while the remaining ones may be 
is a historical apocalypse. Within its pages, Abraham as a mediator, while being on a flight throughout the universe and beyond, gets notified about "the future destinies of the world"16 and about the imminent doomsday. This emphasis placed on eschatology brings $T A$ closer to the Byzantine homilies on the Transfiguration, but we will pay particular attention to some other ideas contained therein. An intermediary between $T A$ and Choumnus' homily, in what concerns the image of luminous cloud, might be Origen's homily De Servatoris Transfiguratone from his Commentary on Mathew, which was also dedicated to the Tabor event. Origen's influence on Gregory of Nyssa is famous, in its turn, so that both levels were like a power-reservoir system.

To bear out my hypothesis, I will adduce some data from Nicephorus Blemmydes' On Virtue and Ascesis (ca. 1265-1266), from Gregory of Sinai's Homily on the Transfiguration (ca. 1346), and from Macarius Chrysocephalus' Homily on the Feast of Orthodoxy (ca. 1365). This data, taken as a whole, may be sufficient for making preliminary conclusions concerning the origins of Choumnus' treatment of Abraham.

\section{The Immediate Context}

The image of Abraham is very rare indeed in the Byzantine Transfiguration homilies, both preceding and following the instauration of the corresponding feast in the Byzantine liturgical calendar during the seventh century. But the immediate context of the image should be found in the homilies of Gregory Palamas first of all.

\subsection{Gregory Palamas}

In Gregory Palamas' thirty-fifth homily $\left(c a .135^{0-1357)}\right.$ Abraham once appears in an important context. Dwelling upon the difference between the Son of God, on the one hand, and Moses and Elijah, on the other hand, Palamas noted

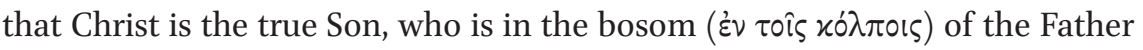
(cf. Jn. 1, 18). "Yet, as far as the prophets are concerned, they will live in the

dated to the period from the fifteenth to the eighteenth centuries. The manuscript A of the long recension (= Paris. Gr. 770) was written in 1315, i.e., in the presumable year of composition of Choumnos' homily. See F. Schmidt, "Les manuscrits," in Le Testament grec d'Abraham, ed. F. Schmidt (Texte und Studien zum antiken Judentum, 11), Tübingen, 1986, pp. 1-3.

16 В.М. Лурье, Введение в критическую агиографию [В. Lourié, An Introduction to Critical Hagiography], St. Petersburg, 2009, p. 196. 


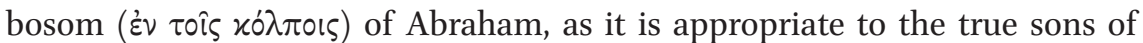
Abraham." ${ }^{17}$ What makes them the sons of Abraham is their faith in Christ that is inextricably intertwined with their entire life.

\subsection{The Letter to the Monks, Theoleptos of Philadelpheia and Theophanes of Nicaea}

From the pseudo-Chrysostom's Letter to the monks (tenth century) ${ }^{18}$ and its aftermath Choumnus might have borrowed the idea of $\mu \varepsilon \lambda \varepsilon^{\prime} \tau \eta$ as a spiritual concentration on God with all one's powers of soul and body.

According to Nicephorus, Abraham left behind all the earthly realities and, "... having overcome the heavens, acquired God the artificer and the wise creator of the things visible and intelligible" (p. 29.12.181-182). Since then, irrespective of what Abraham did or what he thought about, he had God in mind (p. 29.12.182-30.12.185). That is why he took care about matters of hospitality

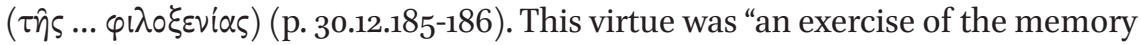
of God ( $\left.\mu \varepsilon \lambda \varepsilon^{\tau} \eta \mu \alpha \ldots \mu \nu \eta \dot{\eta} \mu \eta \varsigma \Theta \varepsilon \circ \hat{v}\right)$, which was incessant within him, and in [his] praxis, which elevates oneself right away ( $\kappa \alpha \theta \alpha \omega \varsigma \varsigma)$ to God Himself" (p. 30.12.186-188).

A certain affinity of this reasoning exists with respect to instructions, which were contained in the Letter. The fact should be pointed out, as the latter text was of great authority for the fourteenth-century Hesychasts. Choumnus' ideas are also close to the teaching of Theoleptos of Philadelpheia, who wrote: “... The memory of God is vision of God". ${ }^{19}$ What is striking here is the obvious similarity between the notion $\mu \varepsilon \lambda \varepsilon^{\prime} \tau \eta \mu \alpha$ and the centuries-long monastic practice of $\mu \varepsilon \lambda \varepsilon^{\tau} \tau \eta$, or instruction/ meditation on the divine Law (Ps. 1, 2). Analogously, $\mu \varepsilon \lambda \dot{\varepsilon} \tau \eta \mu \alpha$ is an exercise or a subject of spiritual reflection, which is closely connected with mental prayer. ${ }^{20}$ But the word $\mu \varepsilon \lambda \dot{\varepsilon} \tau \eta$ could have a wider meaning in the fourteenth century. Thus, half a century later, Theophanes of Nicaea (ca. 1315-1381) recommended to all the faithful a practice of instruction ( $\left.\mu \varepsilon^{\prime} \varepsilon^{\prime} \eta\right)$ in the Holy Scripture. ${ }^{21}$ What is important for Nicephorus is that

17 Gregorii Palamae, Homilia $X X X V$, in $P G$ 151, col. $441 \mathrm{C}$.

18 A. Rigo, "L'epistola ai monaci (e l'Epistola ad un igumeno) di uno Pseudo-Crisostomo: un trattato dell'orazione esicasta scritto nello spirito dello Pseudo-Macario," Studi e ricer-che sull'Oriente Cristiano vi/3 (1983), pp. 197-215, spec. p. 207.

Theoleptos of Philadelpheia, The Monastic Discourses, p. 94.16.185; see also ibid., pp. 94.16.182; 98.20.241-244; 108.33.403-404; p. 116.9.102-103; etc.

20 I. Hausherr, Noms du Christ et voies d'oraison (ocA, 157), Roma, 196o, pp. 123-128, 167-175; В.М. Лурье, Призвание Авраама. Идея монашества и ее воплощение в Египте [Basil Lourié, The Vocation of Abraham. The Idea of Monasticism and Its Realization in Egypt], St. Petersburg, 2000, pp. 48-52. 
Abraham has made hospitality the subject of such a $\mu \varepsilon \lambda \varepsilon \dot{\varepsilon} \eta$. Due to the well thought-out choice of terminology, one of the most essential verges of Abraham's feat was inscribed by the homilist into the centuries-old context of Hesychast theology. The appearance of this notion in a homily addressed to the same nuns, who were accustomed to the sermons of Theoleptos of Philadelpheia, is quite natural.

Let me stress here that Theoleptos, for his part, was the closest to Choumnus in space and time as someone representative of the Byzantine Hesychast tradition. No wonder, then, that there are remarkable affinities between both thinkers' exegesis of Abraham. It was hospitality $\left(\varphi 1 \lambda_{0} \xi_{\varepsilon v i} \alpha\right)$ that mostly attracted God to the от patriarch:

Then [at the oak of Mamre. - D. M.], it was in the same way that God

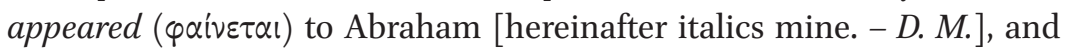
God entrusted himself in his entirety to that person who had believed in him. Thus, he rendered to Abraham, so to say, a reward and exchange $(\dot{\alpha} v \tau i \delta \delta \sigma i v)(\mathrm{cf} . J n .1,16)$ for that faith that he had shown ${ }^{22}$... by this example we can discover two things at once, namely, the way of mercy and the way of hospitality ( $\varphi\left(\lambda_{0} \xi \varepsilon v i \alpha \varsigma\right)$, I mean, how great it could be! It attracts God Himself .... But of still greater importance is the fact that God wanted to make himself known ( $\varphi \alpha v \varepsilon \rho \hat{\omega} \sigma \alpha \mathrm{l})$ to Abraham and that He revealed himself at the same place and at the very table where the patriarch used to take the strangers in (p. 30.13.197-203).

This teaching on a certain completeness of Abraham's unity with God may be compared to Maximus the Confessor's interpenetration doctrine. ${ }^{23}$ However,

22 Compare a similar line of thought in Timothy of Antioch, which is represented as Peter's question to the Lord: "Have you not really rendered blessing to him [Abraham. - D. M.], as a requital ( $\dot{\alpha} \nu \tau \mu \mu \tau \theta i \alpha \nu)$ ?" (Timothei Antiocheni Sermo in Crucem ..., col. $264 \mathrm{~B}) . \dot{\alpha} \nu \tau \imath \mu \iota \theta^{\prime} \alpha$ and $\dot{\alpha} \tau \tau i \delta \circ \sigma \varsigma s$ are the very close synonyms. The editor has underlined the general close-

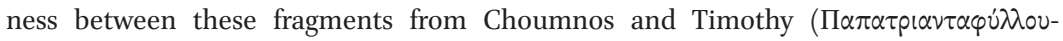

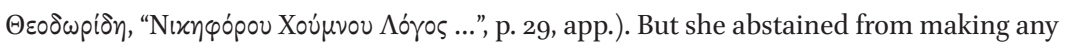
detailed comparison between their ideas.

23 S. Maximi Confessoris, Ambiguiorum liber ..., 7.12, in PG 91, col. 1076CD, 1137BD; Maximus the Confessor, On Difficulties in the Church Fathers. The Ambigua, ed. and trans. N. Constas (DOML), Cambridge, MA-London, 2014, pp. 90-91. From the recent literature on the interpenetration in Maximus see T.T. Tollefsen, The Christocentric Cosmology of St Maximus the Confessor, New York, 2008, pp. 188-189, 212-214, 218; J.-C. Larchet, "The Mode of Deification," in: The Oxford Handbook of Maximus the Confessor, eds. P. Allen, B. Neil, Oxford, 2015, pp. 341-359, here pp. 347-349, 351-352, 354-355. 
Nicephorus' most probable source of inspiration must have been MD 3 by Theoleptos, where the pilgrimage of Abraham was turned into a subject of deep theological reflection. For Theoleptos, Abraham was a stranger in the world and an otherworldly person. Now, in so far as a nun must break her ties with the world and follow Christ, her imitating Abraham turns out to be a necessary stage in her progress. ${ }^{24}$ Indeed, Abraham has departed his father's house, his land and the world (Gen. 12, 1-4) and became a stranger ( $\xi \dot{\varepsilon} v 0 \varsigma)$ in this world. ${ }^{25}$ "And the one who became estranged ( $\dot{\alpha} \pi \circ \xi \varepsilon v \omega \theta \varepsilon i \varsigma)$ from his own people be-

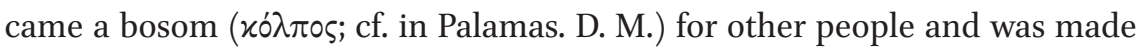
known as a father of nations (Gen. 22, 18; Acts 3, 25)." ${ }^{26}$ Having experienced this estrangement, which is fundamental for a human being and for society at large, Abraham became hospitable. Later on we will see (ch. 3.3) that Theoleptos might have borrowed a considerable part of his reflections on Abraham from the portrayal of the Saint in Gregory of Nyssa's Contra Eunomium. Now let us turn to the role of Abraham in the history of salvation, in accordance with the ideas of Choumnus and Macarius Chrysocephalus, whose thought was in a number of respects close to Nicephorus'.

\subsection{Macarius Chrysocephalus}

Christian symbolism is reflected in Choumnus' utterance concerning all the old-testamentary things and events, beginning from Abraham, as symbols of Christ's miracles (p. 31.15.238-239). Thus, everything connected with Isaac led to Christ (p. 33.17.289-292), "for all these had been archetypes and previous an-

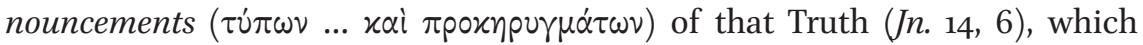
shone today (in the NT times. D. M.), and was revealed to us on Tabor ..." (p. 33.17.292-293). Nevertheless, on the next day, it was to be revealed upon the Cross (p. 33.17.293-297). Theoleptos of Philadelpheia also treated the sacrifice of Isaac as a foreshadowing of the death and Resurrection of Christ in his MD 2,27 but only succinctly.

In fact, Moses' and Elijah's bringing to Tabor had the same aim, i.e., to cor-

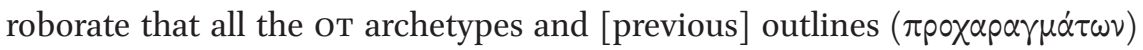
"were now shown on Tabor as being the truth itself" (p. 25.3.44-46), which is centered round the appearance of Christ (p. 25.3.39-41). The Son of God is the

\footnotetext{
24 Theoleptos of Philadelpheia, The Monastic Discourses, p. 154.3.1-3.

25 Ibid., p. 154.2.17-18.

26 Ibid., p. 154.2.19-20. The translation is by R.E. Sinkewicz, ibid., p. 155.

27 Ibid., p. 136.33.424-429.
} 
Truth of the archetypes, ${ }^{28}$ whereas all the things old are but "previous drawings $(\pi p \circ \gamma \rho \alpha \mu \mu \alpha \tau \alpha)$ of the things present" (p. 34.19.333-334). What are these "things present"? What were Choumnus' motives for his alteration of the centuries-old scheme of the salvation history (found, first and foremost, in Maximus the Confessor and John Damascene $)^{29}$ ?

A comparison with Macarius Chrysocephalus (ca. 1300-1382) may help one to understand that, in Choumnus' view, Abraham has surpassed in a way both Moses and Elijah. None of them saw the Face of God during the от period of their lives, whereas Abraham was honored with an extraordinary blessing, when the Son of God sat with him under the oak of Mamre to have a meal. It may be taken in the sense that the Word of God revealed himself to Abraham. Macarius wrote on Moses:

I do not describe that Face of God, which Moses had not seen either on Horeb or on Sinai $(E x .33,23)$, but I observe this one, which was made known on Tabor, and I worship it. ${ }^{30}$

Also the mention of Elijah is important in this connection:

28 The idea that the от things are the archetypes of the Incarnation (and not only of the Transfiguration) is, of course, central for patristic theology. As such, it was expressed and interpreted by many fourteenth-century Byzantine authors. From those not in highlight I would single out Macarius Chrysocephalus. He makes Moses say that the ark of the covenant and the other elements of the Tabernacle were only "shadow outlines ( $\pi \rho \circ \alpha \alpha \rho \alpha \gamma \mu \alpha \tau \alpha)$ of the great mystery" of the Incarnation (Macario Crisocefalo (1300-1382), L'omelia sulla festa dell'Ortodossia e la basilica di S. Giovanni di Filadelfia, ed. G. Passarelli (OCA, 210), Roma, 198o, p. 132.59.13-17; cf. ibid., pp. 133.6o.1-3; 136.66.1-3). Several lines later

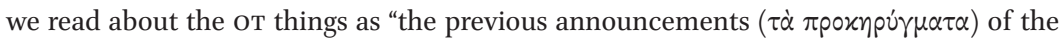
New Testament" (ibid., p. 133.60.5-10). Moreover, the Law itself was only "a shadow outline $\left(\pi p \circ \sigma \chi^{\prime} \alpha \sigma \mu \alpha\right)$ " of the future events (ibid., p. 137.68.5-6). Macarius ruled over the same diocese as Theoleptos of Philadelpheia had done before, and it seems to me to be very likely that he studied Theoleptos' writings. Macarius wrote and preached his homily ca. 1365 or a bit later (Passarelli, Cap. I, "Vita ed opere di Macario Crisocefalo," in: ibid., p. 43).

29 S. Maximi Confessoris, Ambiguorum liber ..., col. 1253C-1256C; Maximos the Confessor, On Difficulties ..., pp. 442-446; S. Joannis Damasceni, Contra imaginum calumniatores Or. II, 23, in: Die Schriften des hl. Johannes von Damaskos, ed. B. Kotter (PTS, 17), Berlin-New York, 1975, vol. III, p. 122; L. Thunberg, "Symbol and Mystery in St Maximus the Confessor. With particular reference to the doctrine of Eucharistic presence," in: Maximus Confessor. Actes du Symposium sur Maxime le Confesseur (Fribourg, 2-5 septembre 1980), eds. F. Heinzer \& Ch. Schönborn (Paradosis, 27), Fribourg, 1982, pp. 298-301.

Macario Crisocefalo (1300-1382), L'omelia ..., p. 141.74.6-8. 
I do not paint in colors the Most High coming to Elijah in "a still small voice" (1 Kings 19, 12), but I engrave ( $\delta$ เ $\chi \alpha \rho \alpha \dot{\tau} \tau \omega)$ the glorious contemplation of him on Tabor by the Tishbite, together with the latter's worship of him. ${ }^{31}$

For Chrysocephalus, therefore, Elijah is the subject of glorification rather because of his being shown the face of God on Tabor, rather than due to his от heroic feats. ${ }^{32}$ I assume that Choumnus treated and depicted Abraham in a similar manner.

So the three stages of the salvation history are, in Choumnus' view, the three Testaments, i.e., OT, NT and the eternal one (p. 34.20.340-348, cf. p. 34.20.338340). The от was done "... in shadows and dark sayings of sorts (cf. 1 Cor. 13, 12) (p. 34.20.340-341)." The NT “... is jointly given today on Tabor ... by the Father, the Son and the Spirit, that is, by the Blessed and all-mighty Trinity, in brightness $(H e b .1,3)$ and in the ineffable light, so that [one] could comprehend Him in a right and clean manner" (p. 34.20.342-345).

The third and eternal Testament was given by Christ on the Cross (p. 34.20.345-348). Within this Testament, Christ gives to those wishing "... the living water (Jn. 4, 7; 4, 14; 7, 38-39), which is always gushing forth and never grows scarce" (p. 34.19.336). This is the uncreated energy of the Holy Trinity, which is given to the righteous as grace. Such an exegesis of the living water is in concordance with its usage in Gregory of Sinai and in his disciple, Callistus I of Constantinople $\left(135^{-1354}, 1355^{-1363}\right){ }^{33}$ The third Testament is, therefore, that of grace, which understanding is not far from patristic eschatology. According

31 Ibid., p. 141.74.9-11.

32 It is remarkable that for Origen Elijah was neither an archetype of asceticism, nor a paragon of monastic solitude (see Д.Ф. Бумажнов, “Семитский и гностический контекст некоторых раннехристианских экклезиологических моделей и их значение для

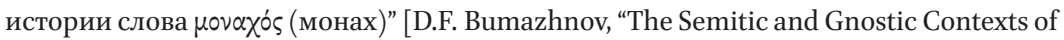
Some Early Christian Ecclesiological Models and Their Meaning for the History of the

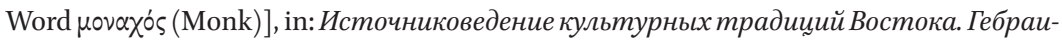
стика-эллинистика-сирология-славистика [Source Studies in the Cultural Traditions of the Orient: Jewish, Hellenistic, Syriac and Slavic Studies], eds. K.A. Bitner [Büttner], N.S. Smelova, St. Petersburg, 2016, pp. 119-136, here p. 131, n. 34). He was to become such an archetype for the Late Byzantine theologians, posterior to Maximus the Confessor. Elijah played the role of paragon together with the Virgin Mary and Melchisedec. See on Elijah's meaning in Maximus Y. de Andia, "Transfiguration et théologie negative chez Maxime le Confesseur et Denys l'Aréopagite," in: Denys l'Aréopagite et sa postérité en Orient et en Occident, ed. Y. de Andia (Études Augustiniennes. Collection Antiquité, 151), Paris, 1997, pp. 293-328, here p. 319 .

Ejusdem [Gregorii Sinaitae], De quietudine et oratione ..., 4, in PG 150, 1309A; A. Rigo, "Cal- 
to its tenets, grace of God, i.e. God, will reveal himself more completely only in the age to come.

On the other hand, the pledge of this future vision of God was given to Abraham, from the formal point of view, under the OT. But the living encounter with God transcends the limits of time and space, making those who experience it a forerunner of the blessed in their eschatological state in the Kingdom of God. It means that: (a) the three Testaments are not rigidly separated from each other in time; (b) Abraham, due to his hospitality and righteousness, and being the father of the seed (Gen.12, 7), turns out to be a witness of a 'small' Transfiguration of the Son of God under the oak. This event can be seen as a pledge of the 'grand' Transfiguration on Tabor.

The pivotal phrase in this connection contains a hidden quote from 1 Cor. 2 , 4, and, probably, from Athanasius' First Epistle to Serapion:

For everything which [happens] to us is faith and power of God (1 Cor. 2, 5), which needs not enticing words of man's wisdom [lit. 'proofs by words',

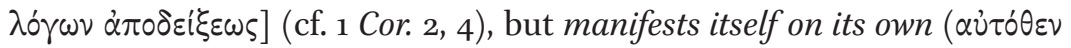

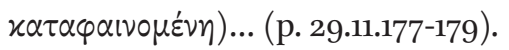

Compare the reasoning of Athanasius: "For the Godhead is not transmitted via

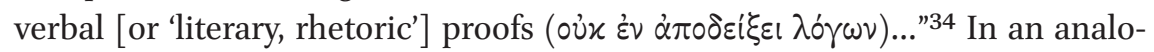
gous manner, Choumnus writes:

God himself, having loved Abraham, came to his guest-chamber ( $\dot{\varepsilon} \pi \dot{\imath} \tau \dot{\nu} \nu$ $\xi \varepsilon v i \alpha \nu$ ) and to his table. He came and showed all the fullness ( $\tau \dot{0} \pi \hat{\alpha} \nu)$ of the Godhead (Col. 2, 9) ... [What he revealed was] the great mystery of the knowledge of God, which had been hidden then ..., but had been saved in Christ (cf. Col. 2, 2-3), and now was made abundantly ( $\varepsilon \dot{\delta} \dot{\eta} \lambda \omega \varsigma$ ) manifest on Tabor, when the Father declared from above, the Son became resplen-

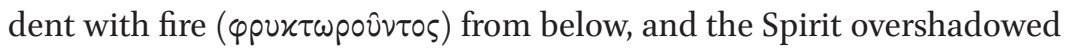
[those on the mount] with a bright cloud ( $\tau \hat{\eta} \phi \omega \tau \varepsilon เ \nu \hat{\eta} \nu \varepsilon \phi \varepsilon \dot{\lambda} \eta)(M t .17,5)^{35}$ (p. 30.12.190-196).

listo I Patriarca, I 100 (109) Capitoli sulla purezza dell'anima. Introduzione, edizione e traduzione," Byz., 80 (2010), pp. 333-409, here pp. 352, 362-364, 388.

34 S. Athanasii Alexandrini, Ep. ad Serapionem I, 20, in PG 26, col. 577A; Athanasius, Werke, vol. I/1, Die dogmatischen Schriften, 4. Lfg., Epistulae I-IV ad Serapionem, ed. K. Savvidis, Berlin - New York, 2010, p. 502.12-13.

35 In $M k .9,7$ and $L k .9,36$ we find simply $\nu \varepsilon \varphi \dot{\varepsilon} \lambda \eta$. 
Thus, in his response to Abraham's faith, God assures the patriarch of his divine existence, by giving Abraham requital ( $\dot{\alpha} v \tau i \delta 0 \sigma \nu, ~ p . ~ 30.13 .197-201)$. It turns out, then, that Choumnus was not very traditional in his comprehension of the three stages of the history of salvation. Usually patristic authors call them оTNT-the Kingdom of God. Instead, in Choumnus we see another periodization: the Law-the Transfiguration-the Cross of Christ [and His Resurrection]. What was the role of luminous cloud(s) in the development of the first and of the second stages?

\subsection{Gregory of Sinai, Macarius Chrysocephalus and Nicephorus Blemmydes}

The bright cloud, which overshadowed those on Tabor, was not the only one either in the Bible or in the tradition of the Church. Let us only remember the descriptions of Christ's Second coming (Mt. 24, 30; Mk. 13, 26; 14, 62; Lk. 21, 27) or the life of Moses (Ex. 19, 9; 24, 16-17, etc.).

Does the image of cloud take any other forms, except the Taboric one, in Choumnus? There are two mentions of it. The first mention seems to balance subtle realism and allegory, reminding me of Origen's approach to the salvation history, even if the latter cannot be reduced to simple allegory. ${ }^{36}$ Each Christian must make flight from the Egypt of $\sin$ (p. 33.18.316-34.18.318). So you don't need to be afraid, Choumnus exhorts his readers, of the Pharaoh's chariots chasing you, for on the rainy day, the bright cloud, which was made manifest on Tabor today, will overshadow you and destroy your persecutors (p. 34.18.318-321). Taking into account the 'average spiritual age' of Nicephorus' audience, we may guess that the meaning of the image of the cloud is here approaching to a metaphor. Nevertheless, it can be extrapolated après coup to Abraham as well. Still, its second usage seems to me to be more realistic in sense: "Let us climb together with Him who is climbing, let us find ourselves within this bright cloud, so as to participate in the brightnesses (cf. Heb. 1, 3) from above" (p. 35.23.379-381). From the text one can see that the light from the cloud (as a common energy of the Trinity) is pronouncedly connected by Choumnus with Christ. This makes me believe that Abraham as well, while receiving as a guest the Son of God, had somehow seen this light (cf. p. 30.12.190196). We are faced in Choumnus, therefore, with the realistic understanding of the Taboric light. In other words, Abraham was shown at the oak the uncreated

$36 \quad$ Scholars point out today that the commonly used opposition "typology-allegory" falls short in properly representing Origen's, Philo's and even Paul's approach to the salvation history (cf. Gal. 4, 24) (see Bucur, “The Early Christian Reception ...”, pp. 264-265). 
light of the Trinity, if only modestly. The appearance of God at Mamre was a manifestation both of his hypostases and of their common energy.

My hypothesis concerning $T A$ 's (and Origen's) influence upon Choumnus' understanding of Genesis 18 in its connection with Tabor can be borne out, then, with some texts by Gregory of Sinai, Macarius Chrysocephalus and Nicephorus Blemmydes. Let us turn to the texts in question.

Let me start from the closest context to that of Choumnus. In his Transfiguration homily Gregory of Sinai $\left(c a .1275^{-1346)}\right)$ rhetorically asks: "For who in the

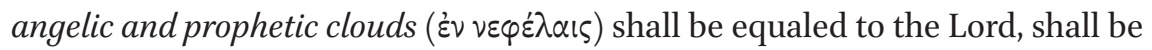
compared to the Lord for favor and will ...? No one. For he is glorified ...."37

Analogously, Macarius Chrysocephalus appeals to his opponent (ca. 1365)

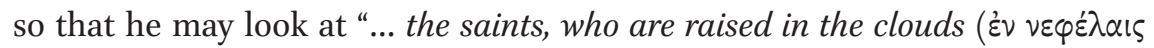

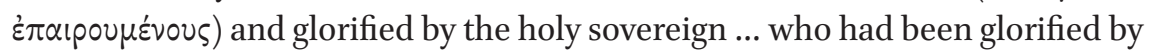
them ...."38

Chrysocephalus does not seem to me to have known Gregory of Sinai's homily, due both to the remoteness of his chair and to the poor manuscript tradition of the text. Yet, in such a case, the textual correspondences between the two texts appear to be the more striking. More than that, the two theologians belonged to two different theological trends (resp., the Athonite Hesychast one, and that of Asia Minor), and even to different layers within those trends. If Gregory was a God-seer and a prominent Hesychast, Chrysocephalus turned out to be a hesitant person, inasmuch as his recognition of Palamism was concerned, ${ }^{39}$ and as a 'middle-level' theologian.

Gregory's expression "the angelic and prophetic clouds" makes me suspect, that he might have been aware of some traditions of Judaic Christian mysticism of chariots (merkavah), like the one which had taken on its shape in TA. If we read Blemmydes' On Virtue and Ascesis (ca. 1265-1266) my hunch might be strengthened.

In his treatise, we run across a picturesque image of practical virtue as a chariot ("o $\chi \eta \mu \alpha)$, lifting up the soul of a righteous one on heaven. This soul is

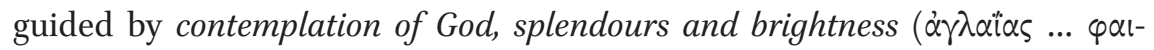

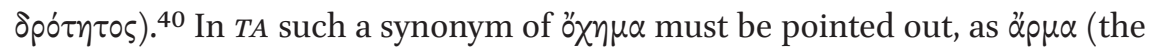
word with a narrower semantics of concretely a "chariot", and not a 'vehicle' in

Saint Gregory the Sinaite, Discourse on the Transfiguration, p. 676.26.437-439. The editor's translation is on p. 677 .

38 Macario Crisocefalo (1300-1382), L'omelia .... pp. 142.77.19-143.77.1.

39 Passarelli, Cap. I, "La vita ...", pp. 33-35, 37-40, 44-45.

$40 \quad$ Nicephori Blemmydae, De virtute et ascesi; Iosephi Racendytae, De virtute, ed. E. Gielen (CCSG, 8o), Turnhout, 2016, p. 31.686-695. 
general).$^{41}$ The word $\alpha_{p} \mu \alpha$ in $T A$, then, and the reality behind it intertwined closely with the image of bright cloud. Second, I would not a priori exclude such a possibility that Blemmydes might have criticized in his Against the Predetermination of One's Death Hour exactly that position that we see in $T A$, to wit, the idea that everyone does have one's fixed hour of death, the only problem being that many people usually die long before that date. ${ }^{42}$

Choumnus could not be ignorant of Blemmydes, because he was a student of Nicephorus' closest adherent in theology, Gregory of Cyprus. ${ }^{43}$ Besides, Choumnus was a contemporary of the dogmatic strife in the Constantinopolitan Patriarchate at the turn of the thirteenth and fourteenth centuries, which was connected with the condemnation of the pro-Latin theology of John XI Veccus and his followers. All these circumstances make my hypothesis about $T A$ 's influence on Choumnus more solidly founded.

\section{The Farther Patristic Context}

\subsection{Origen as a Link between TA and Choumnus}

An intermediary link in the understanding of the image of cloud between Choumnus and the patristic tradition could be Origen's homily no. 557 On the Transfiguration of the Saviour from the commentaries on Matthew. The image of the cloud of light ( $\dot{\eta} \varphi \omega \tau \varepsilon เ \nu \dot{\eta} \nu \varepsilon \varphi \varepsilon \dot{\lambda} \eta)$, overshadowing the righteous, is given special attention here. The cloud is the Father's power, from which the voice proceeded, which witnessed the Son $(M t .17,5)$; it is also the Holy Spirit; it is, at least, the Saviour himself. 44 "For the cloud of the Father, of the Son and of the Holy Spirit overshadows the true disciples of Jesus; or, [to put another way],

41 Let me only adduce an example form the ch. xIV, 6 of the first short recension: when

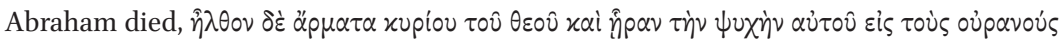
... (“... the chariots of God the Lord came and raised his soul on the heavens ...") (Le Testament ..., p. 82). There exist two Milan manuscripts of this recension, dating back to the eleventh century (F. Schmidt, "Les manuscrits," in: Le Testament ..., p. 2). However, Blemmydes might have known similar ideas from an oral tradition.

42 Le Testament ..., p. 164 (ch. XX, 2 of the long recension); cf.: Nikephoros Blemmydes, Gegen die Vorherbestimmung der Todesstunde, ch. 2, ed. W. Lackner (Corpus Philosophorum Medii Aevi, 2), Athens - Leiden, 1985, p. 2.14-31; etc.

43 C.N. Constantinides, Higher Education in Byzantium in the Thirteenth and Early Fourteenth Centuries (1204-ca. 1310) (Texts and Studies on the History of Cyprus, XI), Nicosia, 1982, pp. 31, 35-36.

44 Origenis, Comm. in Matthaeum, Tomus XII, Nr 557; De Servatoris transfiguratione, in PG 13, col. 1081АB. 
the luminous cloud overshadows the Gospel, the Law and the Prophets for him who is able to see [everything] in its light, according to the Gospel ...." ${ }^{\prime 4}$ It is, therefore, already in Origen that such an interpretation of the luminous cloud took shape, which not only elucidated the corresponding biblical events, but at the same time was oriented towards the future, and tried to integrate the biblical images with everyday life of the Christians. We saw Choumnus using this concept in a very similar meaning when explaining the story of the Pharaoh. What our Byzantine thinker has managed to avoid is any dissolution of the hypostases of the Trinity in the fog of allegories, which was still perceptible in Origen.

\subsection{Timothy of Antioch}

Among those Byzantine homilies on the Transfiguration, which arose from the fourth to the fourteenth centuries, the most valuable are the considerations by Timothy of Antioch $\left(c a .45^{0}\right)^{46}$. Timothy connected the image of Abraham with that of the tabernacle by stressing that the saint had erected such a tabernacle in which Christ entered and stayed for a while ( $\propto \alpha \tau \varepsilon \sigma \kappa \eta \dot{\nu} \nu \omega \sigma \alpha ; \mathrm{cf} . J n .1,14) .{ }^{47}$ It is not accidental that such an eschatological theme emerged in the context of the Transfiguration. The celebration of the event of Mount was closely connected with the от feast of Tabernacles, which was still numbered among the main festivities of the Jews in the first century C.E. 48

I now turn to the theme of Abraham's hospitality in the homily by Timothy. The main point of our author is that Abraham may be seen as a forerunner of St. Peter (Mt. 16, 16; cf. Mt. 26, 63-64; $M k .14,61)$, as he was able to recognizeamong the two angels-the Son of God. For that reason, the от patriarch put up

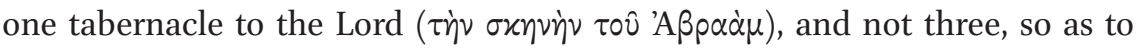
avoid equating the Sovereign with the slaves. Timothy exhorts his listeners, using singular of the verb: "Well, [just] look at the Abraham's faith and at Abra-

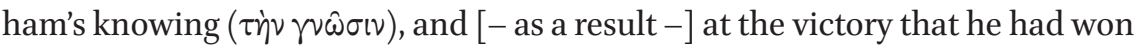
(cf. $1 J n .5,4) .{ }^{m 9}$ What does the exegete understand under the victory? It is, certainly, the outcome of Abraham's feat, i.e., God's appearance to the righ-

$45 \quad$ Ibid., col. 1081B.

46 M. van Esbroeck, "Une homélie géorgienne anonyme sur la Transfiguration," ocP 46 (1980), pp. 418-445, p. 423.

Timothei Antiocheni, Sermo in Crucem et in Transfigurationem Domini nostri Jesu Christi, in $P G$ 86, col. 264BC.

48 E.P. Sanders, Judaism: Practice and Belief, 63 B $B$ E-66 CE, London-Philadelphia, 1992, p. 129. On the meaning of the feast, cf. ibid., pp. 139-141. According to Flavius, its celebration was observed with great punctuality (Antiquitates 15, 50; ibid., p. 139).

Timothei Antiocheni, Sermo in Crucem ..., col. 264BC. 
teous one. "Imitate Abraham, - Timothy advises to Peter, - and put up the tabernacle (cf. Mt. 17, 4; Mk. 9, 5; Lk. 9, 33)."50

Such a conception of Abraham as a forerunner of Peter, who was, in turn, a witness of the Transfiguration, must have been one of the main incentives for Nicephorus to include the image of the holy patriarch into his homily. The Jewish origins of the celebration of the Transfiguration, partly due to the hint at the feast of Tabernacles, are revealed in Timothy's homily most clearly against the background of the Byzantine exegetical tradition.

Now, bearing in mind all the aforesaid, I will analyze the theme of Abraham's faith in Gregory of Nyssa, in its close interconnection with the topic of the vision of God.

\subsection{Gregory of Nyssa. Nicetas Stethatos}

To all appearances, while portraying Abraham, Theoleptos and Choumnus were guided by Gregory of Nyssa's fundamental ideas concerning the knowledge of God. Gregory takes the land, from which the oт patriarch departed, as "the base and earthly way of thinking". ${ }^{51}$ Nothing visible distracted either Abraham's sight or his hearing, but he walked in faith (p. 252.5-10).

Living an ascetical life, Abraham exalted knowledge to such an extent "... that he began to be deemed the summit (öpos) of human perfection ..." (p. 252.11-12). That is how God began to be called personal God of Abraham (p. 252.14-16).

Nothing ordinary could stop the patriarch in his running "beyond the knowable" (p. 252.19-24; cf. p. 253-9-10). Starting from the visible splendor, Abraham

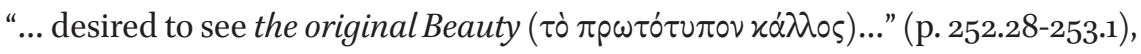
arranging his ways [lit. 'progressions', $\tau \dot{\alpha} \varsigma$... $\alpha \nu \alpha \beta \dot{\alpha} \sigma \varepsilon ı \varsigma$ ] within his heart (Ps. 83, $6=P s .84,5 \mathrm{KJV})^{52}$ (p. 253.7-9). This facilitated Abraham to receive the pure and unmixed faith (p. 253.10-14). So what did he make the unwavering and conspicuous sign ( better and superior to any sign which is somehow connected with our cogni-

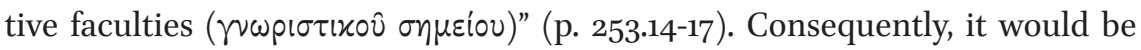
terrible to think that there is nothing exceeding our conceptions about God

$50 \quad$ Ibid., col. 264C. The tabernacle of Abraham is meant here.

$5^{1} \quad$ Gregorii Nysseni, “Contra Eunomium”, 2, 86, in: idem, Opera, Vol. I, Contra Eunomium libros I-II continens, ed. W. Jaeger, Leiden, 196o, p. 252.2-3. Hereinafter I will give references to this edition in the main text.

$5^{2}$ This verse was usually applied to Moses. See Greg. Naz., Or. XXXI, 25-28; Ps.-Dionysius Areopagita, De mystica theologia, 1, 3; Gregorii Palamae, Homilia VI, in PG 151, col. 8oA etc. 
(p. 254.27-30). The notion of God's transcendence was later on to be underlined by Choumnus as well.

In the final part of his analysis of Abraham, Gregory appeals to his readers to live in quietude ( $\delta i$ jouxias) (p. 254.26-27). This is the way Abraham lived, according to $T A$. We read in the ch. I.1 of the long recension that the righteous person had lived for 999 years, always remaining ह่v $\dot{\eta} \sigma u x i \alpha$. He also was $\pi \dot{\alpha} v v$... $\varphi \iota \lambda{ }^{\prime} \xi \varepsilon v 0{ }^{53}{ }^{3}$ In the ch. I.2 we read that he took in everybody-the rich and the poor, friends and strangers. The epithet $\varphi \iota \lambda \hat{\sigma}^{\xi} \xi v 0 \varsigma$ is applied to Abraham again in this connection. ${ }^{54}$ In the final conversation with the patriarch the death tells him that it is only righteous people to whom it comes $\dot{\varepsilon} v \dot{\eta} \sigma u x i \alpha$ quietude [or "stillness"].55

It is remarkable that, speaking about Abraham, both Gregory and the author(-s) of $T A$ use the term $\dot{\eta} \sigma 0 x i \alpha$. But the closeness between Choumnus and $T A$ is multilateral. We will discuss it in greater detail in Ch. 4 below.

An important idea concerning Abraham can be found in Nicetas Stethatos' Antidialexis [lit. 'an answer in course of a discussion'] against the Filioque (some time before 26 June 1054): "And Abraham had received as a guest ... the

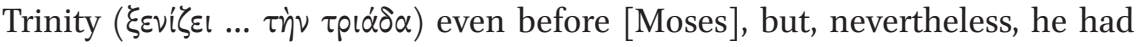
called Him in a singular fashion ( $\dot{\varepsilon} v(x \omega \varsigma)$ ), i.e., Lord." ${ }^{56}$ This idea fits perfectly into the different Orthodox and Judaic contexts which are the subjects of investigation in the present article. ${ }^{57}$ As we see, Stethatos also remained true to the third type of interpretation of Gen. 18 (in Lars Thunberg's terms). He could correspondingly exert some influence on the formation of Choumnus' basic idea.

\footnotetext{
$53 \quad$ Le Testament ..., p. 96.

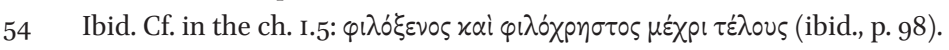

55 Ch. XVII.7, in: ibid., p. $15^{2}$.

56 A. Michel, Humbert und Kerullarios. Quellen und Studien zum Schisma des XI.Jahrhunderts (Paderborn, 1930) (Quellen und Forschungen aus dem Gebiete der Geschichte, 23), vol. 2, p. 381.6-7. On the date cf. ibid., pp. 360-362.

57 We will not enter here into a serious discussion concerning some basic premises of Stethatos' triadology. On this, cf. D. Krausmüller, "Between Tritheism and Sabellianism. Trinitarian Speculation in John Italos' and Nicetas Stethatos' Confessions of Faith," Scr 12 (2016), pp. 261-28o.
} 
It would be relevant, indeed, to begin our analysis of the conceptual correspondences between Choumnus' text and $T A$ with the epithet $\varphi 1 \lambda o^{\prime} \xi \varepsilon v o s$, which we see featured already in the caption of the second version of $T A$ 's short re-

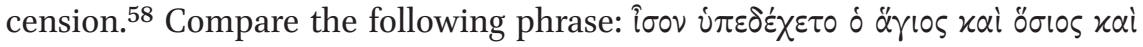

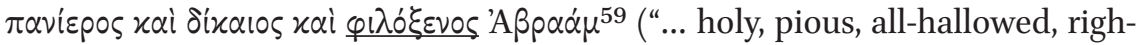
teous and hospitable Abraham equally took in [all the strangers]”). If we add numerous examples of Abraham, of his actions and his household being described with the root $\xi \dot{\varepsilon} v$ - and its derivatives, like $\xi \varepsilon v i \zeta \omega$ ('to receive [somebody] as a guest'), ${ }^{60}$ we will get a very clear picture of parallels between $T A$ and Nicephorus.

Thus, in the first version of the short recension of $T A$ (BHG 2002), archangel Michael, the main intermediary between God and Abraham asked the righteous, saying: "-Let me be received by you as a stranger $(\dot{\varepsilon} \pi ı \xi \varepsilon v 0 \hat{\nu} \mu \alpha \iota) . . . "{ }^{2} \mathrm{Simi}-$ larly Abraham explained to Isaac in the ch. III.6: “... so that we may wash the

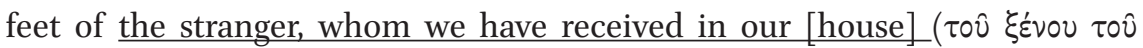

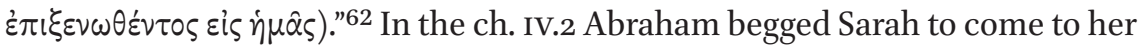
room, "so as not to become importunate to this stranger [lit. 'stranger-man', $\tau \hat{\omega}$

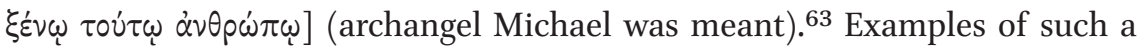
kind abound both from the second version of the short recension (BHG 2002 $)^{64}$ and from the long recension (BHG 2001). ${ }^{65}$ For example, in the final dialogue

$5^{8} \quad$ Le Testament grec d'Abraham, p. 83 .

59 Ibid., p. 96.

6o See also the Index of the Greek words, compiled by F. Schmidt: ibid., p. 190.

61 Ibid., p. 48. Compare in the second version of the short recension: "Let me be entertained

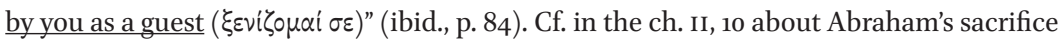
of a bull with the aim of rejoicing the angels, whom he had entertained in his house

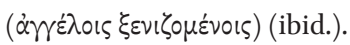

62 Ibid., p. 5o; cf. Cap. III.7. 9, in: ibid., p. 52.

63 Ibid., p. 52; cf. Cap. v.5, in: ibid., p. 56.

64 E.g., in the ch. IV.14 God orders Michael to come to Abraham and to be received by the

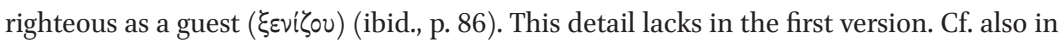
the ch. II.12-"with the stranger ( $\mu \varepsilon \tau \dot{\alpha} \tau 0 \hat{~ \xi \varepsilon ́ v o v) " ~(i b i d ., ~ p . ~ 84) ; ~ c h . ~ I I I .6 . ~} 9$ (p. 85); ch. IV.2 (ibid.); ch. V.2; ch. V.5 (pp. 86, 87); ch. VI.5 (p. 87); ch. III.7 (p. 85). In the ch. IV.10 we find among the set of Abraham's epithets, which Michael enumerates to God, the pivotal one:

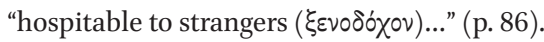

65 Thus, in the ch. II.9 Michael is characterized as "this stranger, coming from afar ( $\dot{o}$

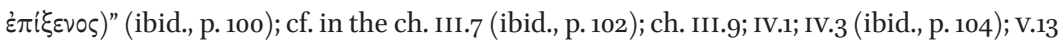
(ibid., p. 110); vi.4 (ibid., p. 112). 


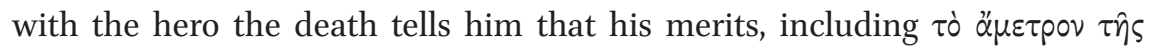
$\varphi 1 \lambda_{0} \xi \varepsilon v i \alpha \varsigma$ $\sigma 0 v$, became a crown upon its head. ${ }^{66}$ In the final clause of the long recension, the brethren (of a monastery?) are summoned to imitate Abraham's hospitality ( $\tau \dot{\eta} \nu \varphi \iota \lambda \circ \xi \varepsilon v i \alpha v) .{ }^{67}$ So, as M.R. James and E.P. Sanders have stressed, hospitality is the main trait of Abraham as portrayed in $T A .{ }^{68}$

Next, I propose to compare with these examples the following sentence of Choumnus, which is of paramount importance for our topic:

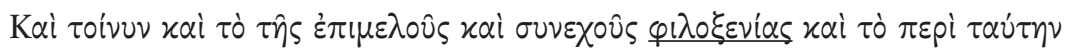

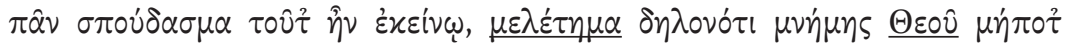

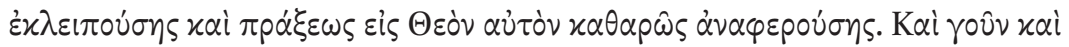

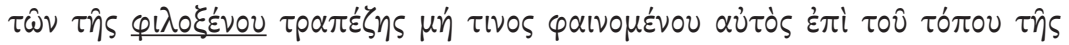

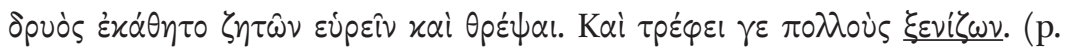
30.12.185-190).

For, indeed, careful and continuous hospitality, and each kind of zeal is - for it was one and the same thing for Abraham, to wit-an exercise in the memory of God, which [memory] was incessant [within him], and in that doing, which elevated him right away to God Himself. And, truly, even as long as no one [among strangers] could be seen, who was to share the hospitable meals [with the righteous one], Abraham sat at that very place, next to the oak, seeking after [such strangers], so as to search them out and to feed them. It is true that he fed many, entertaining them in his house like strangers.

The image of the cloud-chariot from TA might have been one of the closest premises of the reconfigurable image of the 'cloud' at Mamre, which accompanied God in his appearance to Abraham. All the three recensions of the apocryphal story are Judaic in origin. ${ }^{69}$ Nevertheless, the Judaism, represented by $T A$, is "a kind of lowest-common-denominator Judaism."70 That is why it could have been easily adopted by Choumnus and filled with Christian content.

66 Ch. XVII.7, in: ibid., p. $15^{2}$.

67 Ch. xx.15, in: ibid., p. 168.

68 M.R. James, "Introduction," in: The Testament of Abraham, ed. M.R. James (Texts and Studies. Contributions to Biblical and Patristic Literature Edited by J.A. Robinson, Vol. II/ 2), Cambridge, 1892, p. 74. According to E.P. Sanders, the theme of Abraham's hospitality is "the only real connection with the testamentary literature" (Sanders, "Introduction", p. 879).

69 Sanders, “Introduction ...", p. 875.

$70 \quad$ Ibid., p. 876. 
Let us take a closer look at Abraham's transferences in $T A$. There the cloud serves the archangel Michael and Abraham as an all-purpose vehicle in this world and beyond, as, for example, in the ch. viII.3 of the first short recension: "Thus Michael approached Abraham and raised him with his body on a cloud

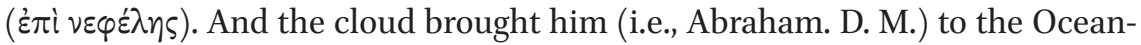
river."71

The same tendency can be found in the long recension. In the ch. IX.8 God orders Michael: “Take a cloud of light ( $\nu \varepsilon \varphi \varepsilon \dot{\lambda} \eta \nu \varphi \omega \tau \grave{\varsigma}$ ) and the angels on chariot, bestowed with power, and take the righteous Abraham to the chariot of the Cherubim, and exalt him up to the heavenly ether, so that he may see the whole universe" (p. 124; cf. ch. XV.2 at p. 144). In the ch. X.1 it is narrated how, "on his condescension, the archangel Michael took Abraham to the chariot of the Cherubim and exalted him up to the heavenly ether. And Michael led him on the

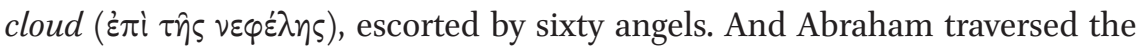
whole universe on the chariot (oxท́ $\mu \alpha \tau \circ \varsigma)$ " (p. 124; cf. the mentions of chariot(s) in the ch. XI.1; XV.12 at p. 128, 146).

If the $\nu \varepsilon \varphi \varepsilon \dot{\eta} \eta \varphi \omega \tau \dot{\zeta}$ (ch. IX.8) was the closest contemporary analogue to the $\nu \varepsilon \varphi \varepsilon^{\prime} \lambda \eta \phi \omega \tau \varepsilon เ \nu \eta \dot{~}(M t .17,5),{ }^{72}$ then the image of chariot (o' $\left.\chi \eta \mu \alpha\right)$, so typical for the Merkavah mysticism, was already to be seen in Blemmydes (see 2.3). The pivotal difference between $T A$, on the one hand, and the Biblical and patristic tradition, on the other hand, lies, however, in the fact, that in the second line of thought the cloud is a way of divine appearance to the just, while in the apocryphal literature it is only an angelic power, or a set of powers, guided by the archangel Michael.

In order to appreciate properly all these concepts and images, one more passage from Choumnus' homily should be recalled. Moses saw Christ shining

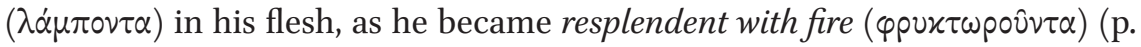
25.3.41-43). His flesh remained unburnt, like the rod of Moses (p. 25.3.43-44). Now we must only remember those deepest ties that connected for centuries Moses and Abraham in the tradition of Jewish and Judaic Christian apocryphal literature. From all the aforesaid it may be inferred, then, that what binds Mo-

71 Le Testament ..., p. 64. Cf. the analogous cases in the same recension: ibid., pp. 68 (ch. X.2), 74 (ch. XII.1; XII.6; XII.9); in the second short recension: ibid., pp. 89 (ch. VIII.3), 91 (ch. X.2), 93 (ch. XII.1; XII.9). Hereinafter I will give references to the edition by F. Schmidt in the main text.

72 It was already M.R. James who wrote about the meaning of the image: "The cloud of light is a common method of conveyance in the Apocryphal Acts of the Apostles, e.g. Acta Andr. et Matth. § 21..." (M.R. James, "Notes," in: idem, The Testament of Abraham, p. 123). 
ses and Abraham together is this common spiritual and prophetic experience of the living encounter with Christ.

Moreover, as Andrei Orlov noted, the description of divine appearances and of his presence as the voice, proceeding from fire, became one of the most essential characteristics of the theology of the Name. ${ }^{73}$ Now, in the Transfiguration scene the voice of the Father proceeded from the cloud, much similar to that which should have served as a vehicle for Abraham, according to TA, whereas it is Christ who was resplendent with fire, in Choumnus' view. It is hardly by chance, then, if we remember $L k .12,49$, which was so important for Callistus I of Constantinople (to cite but one example). ${ }^{74}$ It was Elijah's chariot of fire in the от that had also prefigured the NT flame of Christ (p. 27.7.115-119).

In a word, Choumnus lines Abraham up with such symbolic figures as Moses and Elijah. These righteous men both foreshadowed Christ and met him in their earthly lives. In doing so, Nicephorus came out as a forerunner of the Hesychast treatment of the Virgin as the true Hesychast (Gregory Palamas, Philotheus Coccinus, Theophanes of Nicaea). He also stood at the origins of that general flourishing of Hesychast theology and exegetics, which made the Byzantine fourteenth century a brilliant period in the history of Church and culture.

All these similarities between the texts do not abolish, though, the evidence of the fact that on Tabor it was the Holy Spirit, who overshadowed the apostles and the disciples, whereas in $T A$ the cloud-chariot was guided by the archangel Michael. Such an 'angelic cosmology' of a clearly pre-Nicene type was represented in the fourteenth century by the anti-Palamites, with Nicephorus Gregoras as their head. ${ }^{75}$ But it was exactly the exegesis of Genesis 18 where Choumnus shunned the tradition of $T A$ and kindred literature. For he who appeared to Abraham was, to Nicephorus' mind, not Michael, but the Son of God. Figuratively speaking, that cloud, which overshadowed the elect on Tabor, had

73 Орлов, “Традиции Имени Божьего в “Откровении Авраама” [Andrei Orlov, "Praxis of the Voice: The Divine Name Traditions in the Apocalypse of braham," in: Journal of Biblical Literature, 127 (2008), pp. 53-70], the Russian trans. by Nikolay Seleznyov], in: idem, Воскрешение Ветхого Адама. Вознесение, преображение и обожение праведника в ранней иудейской мистике [The Resuscitation of the Old Adam. The Ascension, Transfiguration and Deification of a Righteous Person in the Early Jewish Mysticism] (Moscow, 2014), pp. 239-267, at p. 251.

Rigo, "Callisto I Patriarca ...", p. 372; cf. Balfour, Saint Gregory the Sinaite, Discourse ..., p. $648 \cdot 4 \cdot 54-56$.

75 Cf.: Nikephoros Gregoras, Antirrhetika I, ed. H.-V. Beyer (WBS, XII), Wien, 1976, pp. 311.3; 313.12; 317.13-14; 321.1; 323.14-15; 327.26. 
earlier shone upon Abraham near the oak of Mamre, and it was the cloud of the divine glory ${ }^{76}$ or of the divine light, that is, God himself.

\section{$5 \quad$ Conclusions}

The consideration of the Transfiguration narratives within the context of от/ NT interrelations is significant, since it is one of the pivotal biblical episodes. Still, the question inevitably arises of how to explain the synthesis of the competing theological paradigms, e.g., that of the divine voice and that of the divine light and fire, in Choumnus' homily? Presumably, the late Byzantine tradition, which emerged after the Areopagite and especially after Symeon the New Theologian, combined the both currents of the ancient Christian theology of communication with God; I mean the teaching on the divine face and that on the voice of God. ${ }^{77}$ Both trends, which constitute the staple of our essay, viz., the mainstream and the substrate trends, interconnect with each other, tending to enter as components into the late Byzantine Palamite theological synthesis. Choumnus was one of its predecessors.

A lay theologian and philosopher, Choumnus deceased in 1327 as a monk in the very monastery of the Philanthropos Saviour, where he had preached the sermon under investigation. He showed himself as a peculiar exegete of the Scripture and a gatherer of different exegetical and mystical traditions. With his treatment of uncreated grace, he anticipated Palamas and his school.

76 Both Moses and Elijah stood before Christ in the glory (Gregorii Palamae, Homilia XXXV, in $P G$ 151, col. 444C-445D).

77 V. Baranov, "Eucharistic Exegesis as a Key to Diverging Spiritualities: From Egypt to Constantinople," Scr, 9 (2013), pp. 26-69. 